\title{
A Peer-Reviewed Article
}

\section{The need of Change in Contemporary Nepalese Foreign Policy}

\author{
Ram Kumar Dahal
}

\begin{abstract}
The year 2017 has witnessed important changes in Nepal including the holding of Central, Provincial and Local elections in course of implementing the federal constitution-the constitution of Nepal, 2015. Besides these national changes, important changes have occurred in regional and global politics. In the changed national, regional and global context, Nepal has to readjust, reorient and reformulate its foreign policy to serve the growing needs and aspirations of its people. Both the internal and external issues and challenges have to be timely and properly addressed by means of an appropriate contemporary Nepalese foreign policy. The nonaligned foreign policy formulated during the cold war period has to develop new mechanisms and capabilities to cope with the changing time and situation, to fulfill the growing aspirations and expectations of the Nepalese people in the present context and to maintain its independent regional and global image and personality. In this context, Nepal has to realize the significance of its specific, unique and peculiar characteristics and convert/transform them as elements of national power and contribute towards strengthening/consolidating its foreign policy.

Keywords: Capability, consolidating, landlock, geo-strategically, negotions, superpower.
\end{abstract}




\section{Introduction}

The contemporary Nepalese foreign policy has been analyzed here on the basis of fast changing national, regional and global milieu. With the beginning of the $21^{\text {st }}$ century, a number of important and unprecedented changes have occurred in Nepalese politics. The post April 2006, in particular, witnessed many revolutionary changes. Nepal has promulgated the Constitution of Nepal, 2015 through the $2^{\text {nd }}$ Constituent Assembly. Nepal is in the process of successful implementation of its new constitution through local, provincial and federal elections. A decade long political transition is about to end and Nepal seems to gain some sort of political stability in the coming years. However, political movements in different parts of the country in different names including identity politics, federalization of the nation, movements in Terai have not been settled completely affecting Nepal's role in global politics. The liberal policies of the Government of Nepal (GoN) in post 1990 days to work with foreign countries in larger framework, tremendous globalization, the revolutionary changes in information and communication technology and a number of national, regional and global factors have increased the expectations and aspirations of Nepalese people in the present context.

Important changes have also occurred in international politics through global waves of globalization, privatization, and liberalization have direct impact (both positive and negative) in the contemporary foreign policy of Nepal. The growing competition (if not rivalry) between the US (the only superpower in the world) and China (emerging superpower and the first economic power in the world in terms of PPP) on one hand and China and India on the other, the growing gap between the rich North and the poor South, the growing south-south cooperation, the competition between the US in global banking sector (the 
World Bank supported by the US) and the newly established bank (e.g. BRICKS, AIIB supported by China) have created direct impact in the foreign policies of small, least developed country(LDC) and landlocked country(LLC) like Nepal. China's greatest proposal of the century, Belt and Road Initiative (BRI) and India's being reluctant to join will have uneasy situation for Nepal. Nepal has decided to join BRI formally and the domestic political changes in Nepal after the previous election, political pundits of the West and South have analyzed that Nepal is inclining towards its North. The traditional Nepalese foreign policy, formulated during the cold war period to adjust its relations with the two superpowers, has failed to address these burning issues of the contemporary global politics. Countries like Nepal have to reformulate, revise, reorient and introduce new foreign policies to cope with the changes taking place in global politics. South Asia has also witnessed important changes in regional politics. The growing relations between India and China, (particularly during the Prime Ministership of Modi), competition and power rivalry between India and China, the growing strategic relationship between India and the US (e.g. particularly Prime Minister Modi's attempts to come closer to the US), the deteriorating relation between India and Pakistan have further created direct impact in the foreign policy of a small nation like Nepal. The future of SAARC has remained uncertain. Under such situation, the contemporary Nepalese foreign policy has to formulate more assertive and dynamic policies and develop new strategies to cope with the changing situation in South Asia.

The basic objective of this article is to analyze the real capability of the existing Nepalese foreign policy and recommend changes according to the need of the time and situation. Attempts, thus, have been made here to analyze the prospects of timely changes 
in the contemporary foreign policy keeping in view of the existing national regional and global context. .The key research questions/statements of the problems formulated to achieve the above objectives are: What is the actual position of present Nepalese foreign policy? What changes can be brought in it in order to make it more functioning? Why are the foreign policy goals not honestly being implemented into practices? It would concentrate only on some important dynamics and dimensions of contemporary Nepalese foreign policy.

In the existing context of new generation disrespecting the country and people and intending to leave the country forever forgetting the concepts like patriotism, and love to the soil/motherland, it is high time to highlight and glorify Nepal's unique peculiarities, specialties and plus points in the world in geographic, sociocultural, political, historical judicial so that they start feeling proud in calling themselves Nepali or being Nepali. In the existing background of Nepali nationalism and patriotism, love to its history, indigenous culture, language, lifestyles becoming weak under the powerful influence of globalization and other global trends, it has become essential to underline/highlight and glorify/praise Nepal's unique peculiarities, specialties and plus points in the world as part of Nepali nationalism. These unique peculiarities, specialties and plus points are found in Nepalese society in its different dimensions including in geographic, historical, economic, socio-cultural, religious, educational and psychological ones.

\section{Scope and Need of Timely Changes in Different Dimensions of Foreign Policy and Diplomacy}

In the present context, the Nepalese foreign policy, formulated during the cold war period to address the ideological issues between two superpowers, has failed to address the burning 
issues of the day. So, timely changes are needed in different dimensions of internal and external environment. The need of changes in internal environment, for convenience, can be broadly subcategorized into possible or prospect of changes in political, socio-cultural, economic, administrative, diplomatic and legal constitutional dimensions, which have been outlined below. Moreover, Nepal's unique and peculiar geographical, historical, socio-cultural characteristics could also be cashed in its foreign policy for the all-round development of the nation by promoting factors like economic diplomacy than heavily relying on direct foreign aid in cash. If such unique and peculiar characteristics could be properly mapped and utilized in foreign policy, they would contribute to develop self-sustained economy in the long run, thus, increasing Nepal's capability in its foreign policy and diplomacy in the present context.

\section{Nepal's unique and peculiar geographical characteristics and prospect of changes}

Nepal has certain unique and peculiar geographical characteristics which could be cashed in Nepalese foreign policy for serving its national interests and for its economic betterment in the long run. Nepal is one of the landlocked countries of the world (or India locked country'), a third pole country, a country of diverse geographic characteristics, country of the Himalayas, including the world's highest peak Mt. Everest, a small country ${ }^{2}$ in comparison to its immediate neighbours ${ }^{3}$, a medium-sized country among the 193 member- states of the UN, a country of Sherpas (highlanders), the world famous trekkers and mountain

\footnotetext{
1 The nearest port of Nepal-Bay of Bengal is $1127 \mathrm{~km} .(700 \mathrm{mile})$ away from Nepal. Bangladesh and Bhutan are respectively 27 and $32 \mathrm{~km}$ far from Nepal.

2 Nepal, with a size of $147,181 \mathrm{sq}$. km. (56827 sq. mile), covers 0.03 per cent, 0.3 per cent and 2.379 percent of areas of the world, Asia and South Asia respectively.

3 Nepal, with a size of 147,181 sq. km. (56827 sq. mile), is 65 and 22 times smaller in size then China and India respectively.
} 
climbers, a country of rare animals, rare vegetation, rare birds, rare flowers, and a country of rare flora and fauna. Nepal's such geographical specialties and peculiarities in different factors including its geo-strategic location, shape and size, border linkages ${ }^{4}$, vital national resources (natural and mineral) circulation, and climatic condition and a number of factors. Topographically and from climatic point of view, Nepal is one of the richest countries in the world. In the present context of fast growing economies of India and China and due to the issues of free Tibet, Nepal, geo-strategically, has become the most sensitive and most important location of contemporary international politics. A number of commercially important transit points to enter $\mathrm{China}^{5}$ have further added its strategic importance in world politics. Geographically, Nepal, a small, peaceful and beautiful country with different geographic characteristics, is the blessing of the nature and the heaven of the earth if its resources can be utilized properly. Nepal has some unique, specialties, peculiarities and characteristics in the world which is not found in any other parts of the world. It is noted for

4 Nepal borders $1414 \mathrm{~km}$ with China and 1590 with India. Nepal borders five states of India. Under the new federalized structure under the new 2015 constitution, out of the seven Pradeshes, two touches border with India, two with China and three with both of the countries. The total 13 districts of Nepal, out of the previous 75 ones, 13 borders with China, 24 with India, two with both the countries, and 36 touching with none of the two countries. Bangladesh and Bhutan are 27 and $32 \mathrm{~km}$ far from Nepal. Nepal, with a size of 147,181 sq. $\mathrm{km}$. (56827 sq. mile), is a small country in comparison to its two immediate neighbours but Nepal is a medium sized country in comparison to 194 states associated with the UN and is larger than three other South Asian countries-Bhutan, Sri Lanka and the Maldives. Nepal covers 2.379 area of South Asia. The total area covered by greater Nepal, before the signing of the Treaty of Sugauli in 1816, was 2, 04,516 sq.km. (KC, 2072/73:760-61) .Nepal's small size has led to the development of small nation psyche/ psychology among the Nepalese political leadership.

5 Those passes including Kodari /Khasa ( in Sindhupslchowk),Kerung,Rasuwa Ghat, and Kuti (Raruwa),Lomanthang (Mustang),OlanchungGola(Taplejung),Hilsa and Yaring(Jumla), Namja/ Namjala pass (Mugu), Larke pass(Gorkha), Tinker(Darchula), Nangpa,Lamabagar and Digarcha(Dolakha) are important ones.

- 87 - Journal of Political Science, Volume XVIII, 2018 


\section{high Himalayas, ${ }^{6}$ its unique water resources, rivers and lakes ${ }^{7}$,}

highest National Parks in the world ${ }^{8}$, varieties of Rhododendron in the world ${ }^{9}$ rich in species of flowering plants ${ }^{10}$. Nepal is rich in Bio-diversity ${ }^{11}$. Nepal is also regarded as the Amazon of Asia. The hidden treasure of its rich biodiversity is not yet fully explored. Many new species could be discovered in Nepal. Nepal has also unique place in the world in the history of flora and fauna $^{12}$. Nepal is also noted for highest national park, airport and

6 Nepal has some unique characteristics in the history of high Himalayas. Nepal. Known as the country of high Himalayas, including the highest peak of the world, Mount Everest, Nepal has 90 peaks over 7,000 metres and 8 peaks over 8,000 metres with the highest peak of the world, Mount Everest. The Tilijotal(lake) (4919 M) and Khumbu him-nadi ( Himalayan river) $(7600 \mathrm{M})$ are situated at the highest level in the Earth.

$7 \mathrm{Nepal}$ is also noted for its unique water resources, rivers and lakes.Arun River is the River from highest area in the world .AndhaGolchi is the World's Deepest George. Arun Valley of Nepal is the World's Deepest Valley. Shooligadh of Nepal is the World's Highest Waterfall. Lugla/Lukla is the World's Highest Pass. Tilicho Lake is considered as the Lake in highest Place. Kaligandagi is considered as the Pauranic River even older than Himalaya/mountains itself acting as a major ecological dividing line of the whole eastern and western Himalaya.

8 There are nearly dozen of such parks in Nepal.

9 Nepal is a country in the world where varieties of Rhododendron are available in the hills and in the lower Himalayas. Nepal is also noted for its unique characteristics for the different varieties of Rhododendron in the world including the Rhododendron Arboriun being the World's biggest Rhododendron so far known.

$10 \mathrm{Nepal}$ is the place of 5890 species of flowering plants which covers $2.4 \%$ of the world's total and over 250 species of endemic to Nepal has more than 360 species of orchid which constitute over $2 \%$ of the world's orchid and comprises $6 \%$ of the world's rhododendron species. Nearly, Thirty six percent of the world's Meconopsis species "poppy" including Blue Poppies are found in Nepal of which four are endemic only to be found in Nepal .Edelweiss is the Austria's national flower. In Austria is almost extinct in the wild but it is found abundantly in Langtang valley.

11 Though small in size, Nepal is rich in Biodiversity in respect to Flora and Fauna. Nepal occupies only $0.1 \%$ of the earth's landmass, but as per size of the country, the country possesses one of the richest genetic biodiversity in the world. Due to its outstanding altitudinal variation, Nepal has many opportunities to farm any kinds of plants from any parts of the globe. Nepal is regarded as the place of 5890 species of flowering plants which covers $2.4 \%$ of the world's total and over 250 species of endemic to Nepal has more than 360 species of orchid which constitute over $2 \%$ of the world's orchid and comprises $6 \%$ of the world's rhododendron species.

12 Nepal is rich in the world in the history of flora and fauna. Bird in Nepal - SinyBabler; Butterfly in highest area - StellariDecumbes (even in the world); Mushroom only in Nepal - Tryafina Nepalesesis. Nepal has unique place in the field of certain animals in the world, which are found only in Nepal, including one of the largest concentrations of Royal Bengal Tiger in the world; Second largest population of One-horned Rhinos is found in Nepal, one of the best habitats for snow leopard.; The only natural breeding ground of the long Snouted Gavial crocodile exists in Nepalese river. Nepal is also known/noted in the world for certain species of birds. Some of the largest wild honeybees are found in Nepal. Nepal has $4.2 \%$ of the world's butterfly species, which is over 650 species of butterflies. Nepal constitutes more than 
hotel in the world. ${ }^{13}$ As one of the Himalayan and mountainous country of the world, Nepal is also known/ noted in the world for Ayurvedic and herbal medicines ${ }^{14}$. As one of the peaceful and beautiful countries of the world, Nepal is an appropriate place for the practice of the science of Yoga ${ }^{15}$. The presence of these rare resources in Nepal is enough to give the impression that Nepal is not the poor countries in the world, but the mental poverty of the ruling and political elites is the main problem. Indeed, Nepal is one of the most beautiful countries on earth or the heaven of the earth but spoilt by dirty politics. UNECO, in 1979 and 1984, has recognized Nepal's geographic, historical and religious importance and included some places in world heritage sites. Nepal is regarded as the third pole and peaceful

$8.5 \%$ of the world's total bird species. Nepal has nearly 870 species of birds, which arguably more than the whole continent of Europe and North Africa combined. Nepal is also known/ noted certain species of animals (in the world of animal kingdom) in the world, including the world's largest herd of Swamp Deer ( e.g in SuklaPhanta in west Nepal ). Nepal is also known/ noted in the world for certain natural resources including the tallest grassland in the world (e.g in Chitwan) .

13 Nepal is also noted for its unique characteristics in the world, including the highest National Park in the world ( e.g. Sagarmatha national park), the Airport at the highest place ( e.g. Shyanvoche Airport), the Hotel in highest place in the world (e.g. Hotel Everest View).

14 Nepal is one of the few countries in the world where rare herbal plants are available in the hills and in the Himalayan regions. Naturopathy, homeopathy and the system of traditional medicines and healing IN nepal are largely influenced by Tibatan Lamaism. Nepal is a unique place for unavailable herbal medicinal and aromatic plants. Thus Nepal has rich incredible wealth in the world in this respect. The sanjinabi booti, in Mountain Dhaulagiri/ Dronachal parbat, is said to have saved the life of Laxman, the brother of Lord Rama in his battle against Ravan in Lanka, as described in Hindu epic the Ramayan. Nepal is one of the few countries in the world where the rare herbal medicines-Yarsha gumba is available in the high Himalayas. Nepal is also known/noted in the world for certain natural resources World is much sought after Ayurvedic. Nepal has an incredible wealth of medicinal and aromatic plants for the preparation of traditional and Ayurvedic medicines.

15 Nepal is a land of the religious priests, Sadhus, Santas, and devotees. The Himalayan region, as one of the most peaceful region in the world, has remained the land of the devotees and Rishis and Marshis for centuries. As one of the most peaceful region of the world, the Mountain and the Himalayan region can become the biggest Yoga centre and a centre of meditation in the world. Swami Ramdev and Acharya Balkrishna in Haridwar, India have made best use of natural beauty in the global preaching and Practices of yoga..Nepal has to learn a lot from them in this direction. Swami Ramdev has made maximum utilization of the practice of the science of Yoga and preaching the whole world about this. Nepal can make maximum use of its beautiful ecology for the preaching of Yoga by establishing hundreds of thousands of Yoga centers in the Himalayan and hill regions

- 89 - Journal of Political Science, Volume XVIII, 2018 
country in the world ${ }^{16}$. It is also regarded as the only country in the world for climbing the High Himalayas and the highest peaks of the world including MT Everest many times and the country is thus noted for the country of the Sherpas( high Landers), the world wide famous mountain trekkers and climbers. The natural beauty, scene and scenery of the mountains and the high Himalayas have attracted the tourists, trekkers and mountain climbers of the world making Nepal the next Switzerland of the world. The Himalayan region, including the Dolpo one of Nepal, has been considered as the "living museum of the world" (Sharma Parajuli, 2072 and 2074).

\section{Nepal's unique and peculiar historical characteristics and prospect of changes}

Historically, Nepal is a country having a rich historical heritage and long glorious past, is one of the 17 oldest states in the world, which was never been colonized by western powers throughout its entire history. Out of the total 194 states associated with the $\mathrm{UN}$, it is one of the oldest states having 5000 years near long history. The state building of Nepal has a long history. There are many countries in the world which have their geographies but very short histories. The people in the US sometimes feel uneasiness/discomfort in their short histories. The US became independent from Britain and developed statehood in 1776, one year after King Prithivi Narayan Shah, the first unifier of Nepal, died in Nepal. In this respect, the US becomes second generation state, independent India (1947) and Bangladesh (1971) becoming the third and fourth generation states respectively for Nepal. Nepal was one of the few countries in the world which for the first time circulated golden coins in fifth century ${ }^{17}$.King

16 Nepal's peace zone proposal was supported by 117 states of the world, thus becoming the part of international law and politics.

17 King Man dev of Nepal for the first time in Nepal in 464 A.D, circulated Mananka coin. 
Jayasthithi Malla and King Ram Shah introduced several social reforms in Nepal. King Ram Shah used to dine only after his entire subjects took their regular foods. King Prithivi Narayan Shah, even though he preferred Biraj Thapa to be his chief Kaji, appointed Kalu Pandey as his chief Kaji simply because his subjects preferred him.

The term 'Nepal' is very old and has been used even in the Athvarvebed( supposed to be written nearly 5000 years ago. This term has its mention in the Kautilya's Arthasastra too. Nepal certainly has to be proud of this (take pride in being Nepali) and celebrate it with great pump and show. In the words of Aditya (2017), "A country that somehow had been able to survive with its sovereignty and independence more or less intact resisting powerful imperial onslaughts successfully in the course of its struggles has more than one reason to celebrate". Historically speaking, Nepal is also known/noted in the world for certain it's specific, unique and peculiar characteristics. When America and Australia was not even born as a nation, Nepal built finest monuments, which are now listed in World Heritages Sites. It is also said that Nepal is the future of Asia's medieval past. Jaraharlal Nehru, who was at Dehradun in prison writing letter on JAN.1, 1934 to his daughter Indira Gandhi, had praised the sovereign status of Nepal and the bravery shown by the Nepalese Gurkhas in the international arena. He stated that Nepal is a "peculiar country...a delightfully situated place, full of natural wealth. It is not a dependent state like Kashmir or Hyderabad... And the brave and warlike people of Nepal"(Nehru, 2003:411). Nehru had further praised the bravery of the Gurkhas of Nepal in invading Tibet (Nehru, 2003:331-332). Nepal is the land of brave and victorious Gurkhas and the bravery has been beautifully admired by the German Emperor William the II. 
As history is the basis of a nation's foreign policy, a charismatic and leadership, good statesman always respects the history so that they can learn lesson from the history and would not repeat the past mistakes. It is the only history that enables the leadership to do that. If the leadership has to formulate Nepal's China policy, it has to have knowledge about the historical facts relating to the issues. Nepal is one of the seventeen oldest states in the world. Nepal, which was listed in the index of 'Atharvabed' representing knowledge (written in 5 thousands year ago) is known for its long history and civilization

\section{Nepal's unique and peculiar socio-cultural \\ characteristics and prospect of changes}

Socio-culturally, Nepal, with rich Mithila, Newari and other cultures, is one of the richest countries in the world in respect to culture. Nepal, with nearly 125 ethnic groups, 123 linguistic communities and ten religious groups, is an interesting place of academic research for the sociologists, anthropologists and linguists of the world who are conducting hundreds and thousands of research on these things. Nepal has certain unique and peculiar socio-cultural characteristics ${ }^{18}$ which could be highlighted in regional and global forums and can be cashed in serving in own interests. Unity among diversity was the popular binding force for the Nepalese into one integrated form. Professor Jeff Rasley has concluded that "beliefs divide us; values unite us" from the cultural wisdom of Rai people of Nepal in his book, GodlessLiving a valuable life beyond beliefs. (http://awesomegang.com/ 18 Socio-Culturally, Nepal is also known/noted in the world for certain it's specific, unique and peculiar Socio-Cultural characteristics. Cultural harmony is the living force of the Nepalese society. The cultures of Mithila region and Kathmandu valley are known as the richest cultures in the world. The Mithila print of gods and goddess are known all over the world. Katmandu is also known as "living cultural museum of the world" and the place of living goddess on earth/in the world. Nepal is one of the richest countries in the world where continuous festivals are celebrated by all ethnic groups. Nepal records, thus, the largest country to observe government holidays to celebrate such festivals publicly.It are said that Nepal has largest moth in the world (Atlas Moth). 
godless-living-valuable-life-beyond-beliefs-jeff-rasley/). Nepal has been recognized as the one of the most diverse society living in peace and harmony that has attracted social scientists. In the context of linguistics, Nepal has been seen as the open lab for linguists in which university graduates and researchers come to Nepal to conduct their research. For instance, University of Texas Arlington has chosen Nepal for the fieldwork for the linguistics and conducting research. (http://www.uta.edu/linguistics/about/ labs/).

The contemporary Nepalese foreign policy in the present changed context has witnessed a number of socio cultural issues, problems and challenges and has not successfully conducted cultural diplomacy. It has failed to consolidate Nepal's religious and socio-cultural relations with countries of the world (e.g. furthering relations with Buddhist countries and their people and with India and its Hindu population). Nepal's unique sociocultural and religious characteristics could be effectively cashed in foreign policy if the leadership is dynamic and visionary. There is strong need in Nepalese foreign policy to promote national unity and integration and religious harmony among different socio-cultural and religious groups keeping intact the social fabric of the nation in the context/background of splitist tendencies developed in the nation in post April 2007 in different names including identity politics, federalization, state restructuring participation representation. It has become a must for the political parties, particularly, at least for the larger parties represented in the $2^{\text {nd }}$ Constituent Assembly, to devise a comprehensive policies, goals, objectives and strategic dealing with foreign policy implications of all these controversial political issues.

\section{Nepal's unique and peculiar economic characteristics}

Nepal, in the present context, is one of the LDCs of the world, 
but it has a number of economic potentialities needed for its economic development, including the vast water resources (regarded as white money), mineral and natural resources, natural beauties, scene and scenery which could be used in attracting foreign tourists. Nepal in the past had self-reliant economy. Kautilya had praised Nepalese economy for the export of six items. The governance of remittances and formulation and execution of appropriate policies to mobilize such money would determine Nepal's economic future.

\section{Nepal's unique and peculiar foreign policy characteristics}

Nepal in different periods of history was ruled by different dynasties including the Gopallas, Mahispala Avirs/Ahirs, Kiraties, Lichhavies, Mallas, Shahs ,Ranas(1846-1950), and Shahs( in post 1950 days) which conducted their foreign policies in their own ways. As no detailed histories have been written about the Gopallas, and the Mahispala, their foreign policies remain unknown. The recorded history reveals that king Ashok of India and Gautam Buddha of Nepal had visited Kathmandu valley during the Kirati period. The Lichhavies had established cordial relations with Tibet and China even adopting marriage diplomacy. The Mallas had established trade supremacy/ monopolization in Tibet, and circulation of Nepalese currency there. King Jaya Prakash Malla, last king of Kantipur, had requested the British to support him against King Pritivi Narayan Shah and accordingly, Cap. Kinloch arrived in Nepal to support him. In 1767, King Prithivi Narayan shah had defeated the British forces led by Captain Kinloch in Pauwa Gadhi, Sindhuli. The humiliating defeat of the British, the then global power, in this guerrilla warfare had heightened the glory of Nepal and the Nepalese army in international arena. After the Nepal -Britain war (1814-16), Nepal was compelled to sign the humiliating 
treaty of Sugauli in 1816, losing vast portions of its territories .During the Rana period, Nepal tried to please the British and accordingly, Jung Bahadur was successful in returning back the territories of Naya Muluk from Britain. In post 1846 days, Rana prime minister Jung Bahadur was successful in getting recognition of Nepal as a sovereign and independent state of the world from the then global powers-Britain and France during his visit to Europe. Rana Prime Minister Chandra Shumsher signed treaty with Britain in 1923 which, for the first time, recognized Nepal and gave the status of a sovereign and independent state of the world (Art.1).The Shahs, particularly king Mahendra and king Birendra, during the Panchayat period, made several attempts to develop Nepal's independent image in international arena. During the Panchayat days and in post 1990 and even after 2008 days(when Nepal was declared a republican state), Nepal has been trying to develop independent international personality in international politics by performing a number of activities. Nepal has been playing an active/effective role in international body in different capacities.( e.g.in the UNGA, UN peace keeping operations, in the groups of least developed, landlocked and small countries); in the NAM, and in regional politics and diplomacy( e.g.in SAARC and BIMSTEC) and in international financial institutions( e.g. the Britton woods institutions-WB, IMF, WTO,) UNCTAD, Group of 77, and UNESCAP. Nepal also stations the office of World Bank, ADB and the SAARC Secretariat, Regional office of UNESCO, OHCHR and UNMIN. Nepal's peace keeping operations in the UN are of particular importance in this direction. Nepal has actively participated in UN peacekeeping operation in different troubled countries and has earned international name and fame for their bravery, discipline, honesty, and dedication. Nepal has strongly advocated the North -South relation and South-South 
relations. .Nepal has signed more than 15 international covenants including the instruments of human rights and ILO documents and thus is a party to them. Nepal's attempts to institutionalize peace, (e, g, peace zone proposal) were supported by 116 countries of the world. In course of developing independent international personality /image/posture in international arena, establishing Nepal as an independent and sovereign nation of the world has established diplomatic relations with more than 130 countries, commercial relations with more than 109 countries and labor relations with 108 countries of the world Nepal has 21 permanent embassies and missions abroad. Similarly, Nepal has 21 residential diplomatic embassies of foreign friendly countries in Kathmandu the exchanges of visits of different foreign and Nepalese dignitaries (e.g. head of the state, head of the governments, ministers and other high-level dignitaries) to each other's countries have also taken Nepal's friendship with them in new heights.(Dahal, 2010; Dahal, 2017:63-103).

Nepal also has certain unique and peculiar historical
characteristics $^{19}$ which could also be focused and highlighted

19 Nepal had already become the temporary member of UN Security Council twice in the years 1969 - 1970, 1988 - 1989 while, more than 60 member states have never been member of Security Council till today.Reference- United Nations Security Council's official website, Retrieved from http://www.un.org/en/sc/members/elected .asp , Accessed in 2015-0120.KingMahendra and Queen Ratna paid a state visit to the United States of America on November 1, 1967. In the joint statement following discussions between the US president Lyndon B. Johnson and King Mahendra of Nepal, president has praised the leadership by His Majesty and they have discussed to "ease world tensions", reviewed the "situation of Vietnam" and "with respect to the Middle East", they agreed to support the efforts of the United Nations.(- Lyndon B. Johnson: "Joint Statement Following Discussions With King Mahendra of Nepal.," November 1, 1967. Online by Gerhard Peters and John T. Woolley, The American Presidency Project. http://www.presidency.ucsb.edu/ws/?pid=28519).King Prithvi Narayan Shah (1769-1775) first imported European muskets through Calcutta, then built weapons factories with help of French soldiers. They were probably associated in the development of Nepalese artillery until 1790s. In the year of 1850, Jung Bahadur had visited colonial power of the world as the representative of the sovereign state while, our neighbours were their colonies. He was the first Nepali prime minister or government authority to get state honours in the court of Queen Victoria of Britain and honoured by Napoleon of France. King Mahendra and King Birendra has paid official visit to France in the years 1966 and 1994 while, president Francois Mitterrand of France have had official visit to Nepal on 2nd and 3rd May, 1983( France in Nepal, Embassy of France in Kathmandu, Retrieved from http:// www.ambafrance-np.org/Bilateral-relations,651 Accessed in 2015-01-20.) Queen Elizabeth 
in regional and global forums in promoting its economic development. Nepal, except few exceptions in history, has tried its best to maintain balanced relations with its two immediate neighbors. Henry Kissinger has praised the successful and balanced diplomatic postures adopted by the Nepalese rulers in the past. In his words:'For centuries, Nepal skillfully balanced its diplomatic posture between the ruling dynasties in China and those in India-offering letters and gifts that were interpreted as tribute in China but recorded as evidence of equal exchanges in Nepal, then holding out a special tie with China as a guarantee of Nepal's independence via- a vis India" 2014: 179).

\section{Nepal's unique and peculiar military characteristics}

Nepal has some unique and peculiar military characteristics in the world. Nepal is a country of the brave Gurkhas who had played very significant role in deciding the fate of two world wars and the brave Gurkhas had shown bravery and were awarded with the highest British military medals -Victoria Cross, which was an important achievement in the history of Nepalese foreign policy. The Nepalese peacekeepers have been playing important role in maintaining world peace working under the UN banner.

\section{Nepal's specific, unique and peculiar religious characteristics and prospects of change}

Nepal is also known/noted in the world for certain it's specific, unique and peculiar religious characteristics. Nepal by religion was world's only one Hindu state before 2008 and currently a secular state having peculiar religious characteristics. Religious tolerance is one of the special beauties of Nepalese society. Nepal is the place of origin of Shaiva and Shakta sections of

II of Bratain has visited Nepal twice during the rule of king Mahendra and king Birendra on 26 February - 1 March 1961 and 17-21 February 1986 respectively.(The Official website of British Monarchy, Retrieved from http://www.royal.gov.uk/MonarchUK/RoyalVisits/ OutwardStatevisitssince1952.aspx Accessed in 2015-01-20.) 
Hinduism. Nepal, the birth place of Lord Buddha, has one of the richest Buddhist icons in the world. In the recorded history of Nepal, not a single drop of blood has ever been shed in Nepal in the name of religious and ethnic riot. Nepal is the birthplace of Lord Buddha, Janaki or Sita .The United Nation has agreed the proposal of developing Lumbini as a World Peace City. Nepal is known as the land of Living Goddess, Kumari. Dolpo in Nepal is the last stronghold of Bonpo religion; Mystic Bajrayana, an important Buddhist sect, is found only in Nepal. To respect the contribution of Lord Buddha towards world peace,the UN has decided to develop Lumbini as the peace city in the world Buddha's statute in front of the UN headquarter in New York has added Nepal's height in international arena.

\section{Nepal's unique and peculiar educational characteristics and prospect of changes}

Educationally, Nepal has a long glorious educational tradition .Jaiprithivi Bahadur Singh had advocated the need of humanitarian education In Nepal from Bajhang district. Nepal has a long established tradition of respecting knowledge and religious figures in formal and informal occasions. In western countries, there was the tradition of assassinating the religious figures and sources of enlightenment who dared to speak the truth and innovate new knowledge challenging the establishment. The great learned and the pioneering figures in the West including Socrates, Bruno, Christ, and Galileo( to mention a few) were all the most important sources of enlightenment of their ages, and were all killed by the establishment on the charge of challenging the so called fact of the time. Karl Marx, who had tried for the emancipation of the working class people of the world, was forced to leave his country and complete his renowned works in exile. Emanuel Kant, who is supposed to the great man 
after Marx, had also to suffer the same fate. In the context of disrespecting the great source of enlightenment in the West, the Nepalese society had the glorious tradition of respecting the great source of enlightenment and religious Gurus/Pandits and is, instead of killing, respecting Lord Krishna for his Valuable Gita. In the court of king Janak of Mithila, Nepal, there were 25 women Bidushises who were for their Sastrartha(religious discussions)..Nepal in ancient period was a unique place in the history of educational enlightenment. ${ }^{20}$.Under such glorious past, Nepal has to undertake such foreign policy which could promote those things in the present context as the modern Japanese stress on the modernization of their culture instead of erasing it.

\section{Nepal's demographic characteristics in the present global context}

In the present context, Nepal is one of the 50 largest countries of the world in respect to population. The adoption, formulation and implementation of appropriate population, labour and migration policies would help Nepal in the increment of remittances, particularly from the Gulf countries.

20 During the time of King Janak in Mithila, Nepal, enlightenment/Sastrartha used to take place in open places where people from different ethnic, linguistic, socio-cultural and economic groups openly participated or used to listen the religious teachings, and used to become conscious or remained informed about almost all the subjects. This enlightenment had become the effective mechanisms of converting masses into active citizens, playing active role in the building of the state and the economic development of the nation. During the ancient period, all groups of people including the crown prince used to get education from the same Guru in the same place and in the same manner which, among other things, contributed them to the development of the feeling of proximity, closeness and oneness, same thinking, making them non-hostile, tolerant and without parochial loyalties. There was no gap and differences in thinking among them. That education system during that period had helped them to formulate one single identity of citizens (e.g. people have different identities, (on the basis of race, sex, class, region, and religion) the citizens have one single identity- the citizens of state. The ancient common education system had played very significant role in making the people the citizens. The people used to feel pride in becoming the citizens of his/her nation (as Lord Ram said- Janani Janma Bhumischa Swargadapi Gariyasi (mother and motherland are greater/ dearer than heaven). During the ancient period, the Rishis/Dharma Guru (representing knowledge) remained above the king (politics).

- 99 - Journal of Political Science, Volume XVIII, 2018 


\section{Transformation/conversion of Nepal's specific, unique and peculiar characteristics in foreign policy and develop them as elements of national power}

The political leadership and the ruling elites in Nepal have to realize the significance of these specific, unique and peculiar characteristics and convert/transform them as elements of national power and contribute in the strengthening/consolidating its foreign policy to meet the growing needs of time and situation in the present context.

\section{Need, Scope and prospect of Changes in Political Dimension}

As there is close relationship between the internal domestic politics and foreign policy, the current situation of political instability, lawlessness and more important to these, the failure of the $2^{\text {nd }}$ Constituent Assembly in framing democratic and inclusive constitution for the nation has created political problem in Nepalese foreign policy. The constitution is the highest legal document that can be regarded as the sources of all visions, including in foreign policy. The failure of the political parties in formulating political consensus on core issues of foreign policy and vital interests of the nation. They have even failed to develop comprehensive document regarding Nepal's foreign policy (e.g. its goals and objectives, strategies, to mention in few), even though their foreign relations departments, have conducted their relations with some countries at party levels. The differences among the major political parties represented in the $2^{\text {nd }}$ Constituent Assembly in matters of foreign relations in such issues, including issues of Nepals relations with its immediate neighbors and big powers, have further created confusions and strong need to introduce changes in the foreign policy of Nepal. 
These factors, including political instability and lengthening political transition, have among other things, created the issues of Nepal's credibility and efficiency in international politics and even creating wrong image in regional and global politics. The traditional Nepalese nonaligned foreign policy has not undergone revolutionary changes that could cope with the changed context of time and situation and fulfill the growing aspirations of the Nepalese people in the present context. The failure of the $1^{\text {st }}$ Constituent Assembly in framing democratic and inclusive constitution in its four year period and the political controversies even among the political parties represented in $2^{\text {nd }}$ Constituent Assembly and the transformed Legislature Parliament and lengthening political instability and political transition have led to the non demonstration of clear direction, vision and non or less performances in foreign policy and diplomacy, making Nepal's position in regional and global politics weak. The polarization of foreign policy bureaucracy along party lines, the practices of issuing irresponsible and even controversial statements by responsible leaders and authorities in different forums, have also added confusions contemporary in foreign policy. The controversial terminologies including "Common River", "common currency", "common market" and "common security" formulated in the joint communiqué signed between Nepalese Prime Minister KPBhattarai and Indian counterpart in New Delhi on June 10, 1990 have added further new confusions in Nepalese foreign policy. A number of issues and problems also exist in Nepalese public administration creating problems in foreign policy bureaucracy (Ministry of Foreign Affairs (MoFA)) as part of Nepalese public administration even in the present day world, remain illequipped, less competent, less efficient, less capable, extremely polarized on ideological grounds (as part of Nepalese overall bureaucracy), and is operating in traditional 
style. Moreover, the absence of inter-ministerial cooperation and coordination (e.g. among Ministry of Finance, MoFA, Ministry of Labour and Ministry of Commerce dealing with different dimensions of foreign policy). These factors, among other things, have further developed confusions in foreign policy and have led to credibility of Nepalese foreign policy and diplomacy in international politics. A non-politicized, well integrated, disciplined, capable, modern/scientific, well equipped and well trained foreign policy bureaucracy (MoFA) would increase the credibility of Nepal's foreign policy in international politics.

The domestic politics is also reflected in the foreign policy of a nation. Nepali politics in practice has certain specific characteristics and unique nature. The nature of Nepali politics during the Panchayat period has been beautifully presented by former PM Dr. K.I. Singh when a public speech in Tundikhel (open air theatre) in Kathmandu on Nov. 3, 1979 stated: "The king does not hear and Lord Pashupatinath does not speak." Where do we go in the situation? The system of government has been continued to rule out the basis of stick and blow (force). The people do not have courage, the leaders do not have good sense, and the king has been surrounded by these three circles" (Nepali Times, Nov. 4, 1979). The nature of Nepali politics has not undergone any substantial changes in 2015. The trend of encircling the ruling elites by vested interests still continues in the same manner, no matter the hereditary monarch was replaced by elected head of the state. That political character still continues in Nepal.Nepal had already become the temporary member of UN Security Council twice in the years 1969 - 1970, and $1988-1989$ while, more than 60 member states have never been member of Security Council till today. 


\section{Prospects of changes in Economic dimensions}

Nepal during the pre-modern period remained self sufficient. Chanakya in his "Arthasasthra" has mentioned that Nepal used to trade of timbers and woolen with India which is the proof of Nepal's trade was strong during that period. Nepal's whole economic foreign policy ( e.g accepting foreign aid, loan and assistance) and economic diplomacy have to be targeted to promote self sustained/self reliant economy in the present context. Keeping in view of Nepal's existing economic situation (e.g. from bad to worse) and the emerging economic progress of its two immediate neighbors, attempts have to be made with an intention of promoting its economy and developing self sufficiency by adopting very practical economic policies and measures to address the real economic needs of the society including promoting the mandates of social security and justice, welfare state, social market economy, and pro-poor activities/ planning (or putting the last first) to mention a few. Moreover, very practical policies and measures have to be declared and formulated in taking economic advantage out of the economic progress of its two immediate neighbors. The burning economic issues of the day including poverty, unemployment and issues of proper regulation of remittances have also to be very practically addressed while determining Nepal's economic foreign policy and economic diplomacy. The global political and economic actors and global and regional banking groups (including World Bank, IMF, ADB) have also failed to take effective measures in the all-round economic development of Nepal The foreign aid remain mostly misused by the ruling and the political elites. These things could have been effectively raised in the election manifestoes of the political parties.

Under the present age of globalization, the global economic reforms as advocated by the world Bank, including liberalization, 
and privatization, ; and the global waves of democratization and human rights have also practically developed constraints among the leadership, who think better to serve the foreign masters than serving innocent but sovereign people. The leadership comes in touch with the regional and global networking which inspires the leadership to be less accountable to their voters. Under the influence of globalization, the external actors//factors are also playing role in the destabilization of Nepalese society. These regional and global factors have also played negative roles in the non-formulation and non- implementation of FP in Nepal. Under such situation, reforms have to be introduced in Nepalese FP to cope with those regional and Global bottlenecks and pressures.

\section{Prospects of changes in Psychological dimensions}

The contemporary Nepalese foreign policy is also overloaded with some Psychological issues, problems and challenges. In the context of the existing inferior psychology or fear psyche of the ruling and political elites that Nepal is a small country in between two of immediate neighbors and cannot bargain with them for the cause of nation's national interests. Under such situation, attempts could be made to boost up the level of moral and self confidence (in the context of small nation psyche/ psychology) among them and also other stake holders in foreign policy including the people. The contemporary Nepalese foreign policy, in order to meet the growing needs, expectations and aspirations of Nepalese people in the changed national, regional and global context in the 21 st century has to address the issues in psychological dimension and replace the mentality of the ruling elites in course of conducting Nepal's foreign and external relations. In the existing background of political instability, lawlessness and chaotic situation in the transitional period, the 
ruling political elites have failed to present a proper picture and image of the nation in outside world (e.g. in regional and global forum/level) and give positive posture in the context of Nepal's deteriorating international image. In course of pursuing foreign policy goals, objectives, strategies and promoting the national interests and conducting successful negotiations with nations and bargaining with nations, the feeling of small nation psychology among the ruling circles (e.g. that a small country like Nepal cannot effectively bargain for the cause of nation's interests with big countries its) has developed defeated mentality in foreign policy. The domestic instability and political transition has not boosted up the morale of Nepalese negotiators and diplomats at regional and global levels. In the context of Nepal's past glorious image (e.g. of a pound, brave and one of the seventeen oldest states in the world), the morale of the political leadership and the defeated mentality in foreign policy has to be replaced in future

\section{Scope and prospect of Changes in Diplomatic Dimension}

The contemporary Nepalese diplomacy has witnessed a number of weaknesses and challenges at operational level. In order to cope with the fast growing changes in international, regional and domestic politics, Nepalese diplomacy, in course of promoting its national interests, objectives, goals and strategies, has to promote efficient and effective negotiation and dialogue skills (bilateral and multilateral), collective bargaining in regional and global forums (e.g. in the groups of LDCs and LLCs) for promoting of multilateralism. The instruments and institutions of Nepalese diplomacy have to effectively operate in making foreign policy and diplomacy dynamic and successful in the days to come. The politicization of bureaucracy and governmental instability, absence of institutional memory, Nepal's declining regional and international credibility and prestige, undiplomatic behavour of 
foreign diplomats in Nepal, issues of making foreign service more credible and accountable, lack of effective training to Nepalese diplomats working in diplomatic mission abroad (e.g. even in simple diplomatic etiquettes) have reduced the credibility and image of Nepalese diplomacy in global and regional level. The growing foreign interests and concerns (in soft language) in the internal politics of Nepal and foreign dictate/intervention (in the hard language) have also created serious bottlenecks in the effective formulation and conduct of foreign policy ${ }^{21}$.

\section{Scope and Prospects of changes in Psychological dimensions}

Nepal's degrading international reputation, name and fame, and degrading quality of diplomacy, (due to the existing political instability at home and lengthening political transition it has become high time to review these things and adopt concrete measures to regain Nepal's lost prestige and also erase the tag of a failed state, incapable state, to mention a few. These things could help in preserving its independent regional and international personality in the comity of nations as a sovereign state.In the context of growing foreign interest, and concern (in soft language), and intervention (in crude language) in Nepal's internal politics by the external actors/forces due to Nepal's growing strategic importance in regional and global politics, the ruling and political leadership has to be very practical in preserving Nepal's independent status in global politics through

21 The political parties tried to interpret foreign intervention in their own ways based on theory of convenience. If a foreign activity served their interests, the parties tried to justify that activity in the name of people and democracy. But just opposite to this, when their interests are not served, than they called it foreign intervention. The parties are giving red carpet welcome to the foreigners and /foreign elements at the cost of the citizens of the nation. In this connection, it reminds us how Krishna LalAdhikari in the introductory part of his well-known book MakaikoKheti (Cultivation of Maize) in 1920 intended to promote the nationalist sentiment in his satirical remarks in the following words:"...Foreign dogs were better treated would not do as good a service as (the native) street dogs of Nepal to drive away thieves and robbers (unsocial elements)." 
practical and timely policies. Regarding the growing diplomatic intervention in Nepal's internal affairs against the spirit of Vienna convention, very practical and timely electoral pledges have to be made keeping in view of the national interests, objectives and goals of its foreign policy. To deal with the growing policy intervention in Nepal and loosing policy sovereignty of the weak Nepalese state, practical policies have to be made to improve the sovereign status of Nepal. The policies mostly made by the external forces, including international donor community, are less contextual. The policy intervention in Nepal by external forces has to be reduced so as to promote its own assertiveness in formulation of its own policies.

\section{Need, scope and prospect of changes in communication dimension}

In the context of the present globalized world, which can be characterized, among other things, as the high development of modern and up-to-date communications, networks and revolution (e.g. Internet revolution), Nepal has to develop comprehensive modern communications infrastructures suited to the needs of the Nepalese diplomats abroad and the needs of present scientific world as a whole. In the absence of effective communicative skills and capabilities among the negotiators and diplomats, Nepal has also failed to promote its national interests, goals, objectives and strategies in regional and global forums. The physical communications infrastructure networks serve as the basis of Nepal's external linkages with the outside world. In order to make MoFA/foreign ministry bureaucracy and Nepalese diplomatic missions abroad capable to meet the needs of the time and situation, the development of competent communications networks and mechanisms become a must. Nepal has to address these issues and problems in order to make its foreign policy 
and diplomacy dynamic and successful in regional and global forums.

\section{Scope and Prospects of changes in security dimensions}

Nepal, in course of promoting its national interests in regional and global forums, fulfill the expectations of the people and develop independent regional and international personality, has to address the existing security related issues, problems and challenges. During the two and a half decade of multi party experiment in Nepal (1990-2015), the elected governments failed to formulate sound, practical and comprehensive defense policy in dealing with the external/outside world. The Nepalese Army has been playing very significant role in maintaining world peace under the UN banner but the Nepalese political leadership has not been demonstrating positive attitude to boost up their morale in international level and praise their bravery openly. The lack of sound, comprehensive and practical defence policy and the failure of the elected government to address the above issue have raised issues in the credibility of Nepalese foreign policy. As security is the core of any policy, the declaration of such policy is a must in every aspect, including the governance of peace keeping mission abroad. The contemporary Nepalese foreign policy, however, has demonstrated some capabilities in some sectors. ${ }^{22 *}$

22 Nepal welcomed Indian Prime Minister Modi which further renewed Nepal India relations. During Indian PM Modi's visit to Nepal in Nov. 2014, India had formally provided a line of soft credit of US $\$ 1$ billion (approx. Rs. 100 billion to the government which would be used to build the Kathmandu-Tarai fast track road-976 km highway linking the capital with the southern plains (The Himalayan Times, July 8, 2015: 1). The Modi Government has shown positive attitudes in many respects which shows India change in mood, if not interests. Nepal had welcomed the improving relation between the US and Cuba and their decision to reopen their embassies in each other's capital which is really a major step in the relations between the two countries (The Himalayan Times, July 8, 2015: 3). In order to promote economic diplomacy and attract foreign tourists in Nepal, the MoFA had directed embassies to encourage foreigners to visit Nepal campaigning with the slogan that Nepal is a safe place for tourists (The Himalayan Times, July 8, 2015: 5). 


\section{Scope and Prospects of changes in Nepal-India and Nepal-China relations}

Due to nearly $1800 \mathrm{~km}$. open border with India, a number of challenges exist in Nepal India relations. In order to preserve the charms and beauty of Nepal-India relations, the existing issues and problems between the two countries have to be timely, properly and diplomatically resolved. The political issues and problems between the two countries among other things, include, India's traditional, unilateral and narrow concept of security towards Nepal (as defined by Nehru government during 1950's as Himalayas as the security frontiers), India's heavy involvement in Nepalese politics in post April 2006 days, India's non cooperative attitude towards the Bhutanese refugees problems in Nepal, boundary disputes with India (e.g. Susta and Kalapani), issues of border regulation/management, India's institutionalization of 1950 treaty and Nepal's stand on the revision of the treaty and India's repeated emphasis on special relationship with Nepal), the recruitment of Gorkha soldiers, India's stand on signing of new extradition treaty and extraditing criminals, controlling trans-border crimes, contraband goods, illegal border trade and terrorist activities. India' security concerns in Nepal and utilization of Nepal's water resources are its core security concerns in Nepal. Further, India imposed virtual economic blockade in Nepal during the post-earthquake period for the issues of the promulgation of new constitution of Nepal. The two countries have demographic, economic, environmental and psychological issues and problems which also needs timely solutions.

There are no serious issues in Nepal-China relations. There exist some issues between them which the contemporary Nepalese foreign policy has to solve to continue its cordial and good 
friendly rations with China. Nepal has adopted one China policy considering Tibet as the part of China. The only thing China wants from Nepal is that no anti-Chinese activities be conducted from Nepalese soil. Nepal has remained the close partner for the Belt and Road Initiative which was recently launched by China as one of the greatest proposal of the century. Nepal should be clear on its proposals and developmental support from China.

\section{External pressures in Nepalese foreign policy}

Nepal in post April 2006 has to face a number of external pressures in its relations with the external world. The free Tibet movement supported by the Tibetan revolutionaries having their bases in India and other western countries has created problems in the foreign policy of a small country like Nepal. These countries during the demonstration against the Chinese in front of the Chinese embassy in Kathmandu in 2006 had strongly advocated the human rights of the Tibetans and had pressurized Government of Nepal (GoN) not to take action against them. The smaller Europeans nations are also involved in different activities which have added new issues in Nepalese foreign policy. Nepal has to face pressures from international donor community and external players, actors and movements. Nepal in the contemporary situation has to play effective role in maintaining independent regional and international personality in global politics (e.g. in the UN, specialized agencies, in the group of least developed countries (LDCs), landlocked countries(LLCs) and small countries). Nepal has to further improve its relations with the UN because of Nepal's involvement in the peace keeping operations within the UN. Nepal has to be very active in regional (e.g. in the SAARC, BIMSTEC) and global forums (including in specialized agencies of the UN). In post earth quake days, minor misunderstandings have developed in Nepal- 
UN relations when issues of low quality food supplied in Nepal by World Food Program (WFP) was raised within the legislature parliament. The UN blamed red tape for delay in relief delivery to quake victims. John Giry, the Director of The operations for the UN Office for Coordination of Humanitarian Affairs refuted saying that the low quality foods distributed of WFP in Nepal is nonsense (The Himalayan Times, July 2015: 5). During and in post earthquake days, a number of issues regarding the code of conduct of foreign countries and their diplomats in Nepal were also raised. On June 25, 2015, the donors also demonstrated their conditional support to Nepal stating that if the aid amount would be properly utilized for the cause of the real people, they would continue their further aid. The donors had clearly expressed their mistrust on the government due to rampant corruption in Nepal. Under such situation Nepal has to improve its image in global politics by introducing some internal reforms including good governance. Jean-Paul Sartre, in a long preface of the book by Fanon (, 2001, pp. 7-26 has very beautifully remarked the situation of the Europe-trained third world scholars. "The European elite undertook to manufacture native elite. They picked out promising adolescents; they branded them, as with a red-hot iron, with the principles of western culture, they stuffed their mouths full with high sounding phrases, grand glutinous words that stuck to the teeth. After a short stay in the mother country they were sent home, white washed. These walking lies had nothing left to say to their brothers; they only echoed."

\section{Conclusion}

The global power is gradually shifted towards East from the West. Nepal in the changed national, regional and global context has to readjust, reorient and reformulate its foreign policy to serve the growing needs and aspirations of its people. Both the 
internal and external issues and challenges have to be timely and properly addressed by the contemporary Nepalese foreign policy. The nonaligned foreign policy formulated during the cold war period, has to develop new mechanisms and capabilities to cope with the changing time and situation and to maintain its independent regional and global image and personality. Kissinger (1995) in his well known book diplomacy has stated"Travelers, there are no roads; the roads are made by walking."

\section{References}

Aditya, Anand (2017). Festivals for citizens: Its significance, The Himalayan Times Sept 20, 2017.

Dahal, Ram K. (2010). Dynamics of Nepal's Foreign policy, Sangam Journal, Sangam Institute, Kathmandu, Nepal vol.2, Issue 3,Sept. pp.71-90.

Dahal, Ram K. (2017). Principal External Dynamics of Contemporary Nepalese Foreign policy, Journal of Political Science, Central Dept. of Political Science, TU, Kirtipur, Kathmandu, Nepal vol. XV, No. 3,. pp.63-103..

Fanon, Frantz (2001). The Wretched of the Earth (preface by Jean-Paul Sartre, Translated by Constance Farrington), London: Penguin Books preface (pp. 7-26).

http://www.uta.edu/linguistics/about/labs/

http://awesomegang.com/godless-living-valuable-life-beyond-beliefs-jeffrasley/)

K.C., Rajendra (2073/74). Nepalese Army Officer Cadet Darpan, Kathmandu: Pinnacle Publication.

Karki, R. (2015). Trilateral strategic cooperation: Nepal's Foreign Policy Agenda for $21^{\text {st }}$ century in Sangroula, y. and R. Karki (eds) Geo-strategic Challenges to Nepal's foreign policy and way forward Kathmandu: Kathmandu School of Law,pp.285-336.

Khanal, S.N. (2017). Nepal's Science and technology in 2030 in Sharma, S.R., BR Uperti and K. Pyakurel (2015) (eds) Nepal 2030:A vision for peaceful and prosperous Nepal. New Delhi: Adroit Publishers, pp.3548. 
Kissinger, Henry (2014). World Order Reflections on the Character of Nations and the Courses of History. London: Allen Lane, an Imprint of Penguin Books, p. 179.

Kissinger, Henry (1995). Diplomacy. New York: Touch Stone edition, Rockefeller centre.

Nehru, Jawaharlal (2003). Glimpses of world History. New Delhi: Jawaharlal Nehru Memorial Fund OUP.

Nepal's Foreign Affairs (1973-1978). Review of Development in Nepal's Foreign Affairs, 1984-1987; and Report on Nepal's Foreign Affairs,, 1990-1993.

Nepali Times, Nov. 4, 1979

Pun, S.B. (2017). Nepal's water resources in 2030 in Sharma, S.R., B.R. Uperti and K. Pyakurel (2015) (eds) Nepal 2030:A vision for peaceful and prosperous Nepal. New Delhi: Adroit Publishers, pp.59-96.

Sangroula, Y. and R. Karki (eds) Geo-strategic Challenges to Nepal's foreign policy and way forward, Kathmandu: Kathmandu School of Law.

Sharma Parajuli, Bisnu P. (2072). Tibbet Yatra (Travel to Tibet). Kathmandu: Bhudi Puran Prakashan.

Sharma Parajuli, Bisnu P. (2074). Dolpo: Biswoko Jibit Sangrahalaya (Dolpo:the Living Museum of the world), Review of Development. Kathmandu: Bhudi Puran Prakashan.

The Himalayan Times, July 2015: 5

United Nations Security Council's official website, Retrieved from http:// www.un.org/en/sc/members/elected.asp, Accessed in 2015-01-20)

United Nations Security Council's official website, Retrieved from http:// www.un.org/en/sc/members/elected.asp, Accessed in 2015-01-20

Upreti, B.R. (2017). in Sharma, S.R., B.R. Uperti and K. Pyakurel (2015). (eds) Nepal 2030:A vision for peaceful and prosperous Nepal. New Delhi: Adroit Publishers, pp.121-139. 